\title{
Leveraging firm innovation performance through alliance portfolios in emerging economies: the role of absorptive capacity
}

\author{
T. Diana L. van Aduard de Macedo-Soares ${ }^{* 1}$, Fábio de Oliveira Paula ${ }^{1}$, Hudson Lima Mendonça ${ }^{1}$
}

\begin{abstract}
Firms are increasingly engaging in alliance portfolios/networks - AP/Nets - to leverage their innovation performance -IP - and thus boost their competitiveness. Most studies, with a few exceptions especially from emerging countries, found a positive relationship between AP/Net and IP, depending on portfolio characteristics and firm absorptive capacity - AC. This article undertakes an empirical investigation of the AP/Net - IP relationship and AC's potentially moderating role in this relationship in an emerging country: Brazil. Statistical testing of hypotheses regarding these relationships, and $\mathrm{AC}^{\prime}$ 's role, corroborated the exceptions. However, it confirmed how important it is that firms in an emerging country ensure a high level of AC to mitigate the negative effects of AP/Net diversity on IP. Some managerial and policy implications were also formulated.
\end{abstract}

Keywords: innovation; alliance portfolios/networks; absorptive capacity; emerging countries; Brazil.

Submitted: March $6^{\text {th }} 2017$ / Approved: November $20^{\text {th }} 2017$

\section{Introduction}

Open innovation (Chesbrough, 2003), defined as a concept according to which firms make use not only of internal but also external knowledge to generate innovation, has become a necessity (Chesbrough, 2003; Dahlander \& Gann, 2010; Laursen \& Salter, 2006; Randhava, Wilden \& Hohberger, 2016) to contend with increasingly complex technologies. In addition to dyadic partnerships, firms in various industries have established alliance portfolios in the scope of their innovation-oriented strategies. Consistent with our network theory approach, alliance portfolio is defined here as an ego-centric network (Knoke, 2001), or ego-net for short, i.e. the network formed by the focal firm, its direct linkages and the linkages between its partners (Ahuja, 2000; Ozcan \& Eisenhardt, 2009); hence our abbreviation of alliance portfolio as AP/Net. AP/Nets are thus made up of multilateral alliances that nowadays constitute around $27 \%$ to $50 \%$ of all alliances, particularly in technology intensive firms (Xu, Fenik, \& Shaner, 2014).

Participation in AP/Nets is considered important for firms that seek to increase their innovation performance - IP (Faems, Van Looy \& Debackere, 2005; Duysters \& Lokshin, 2011). However, AP/Net's role in enhancing IP depends upon its characteristics. Gulati, Nohria and Zaheer (2000) argued that the alliance network could "serve as a source of both opportunity and constraint" (p. 207); depending on the network's structure and access to resources it provides, it could be a "source of competitive advantage" (p.207). Based on his literature review, Wassmer (2008, p. 150) stated that "the configuration of a focal firm's AP ...determines the quality, quantity, and diversity of information and resources to which the focal company has access".

Zaheer, Gözübüyük and Milanov (2010) identified network characteristics for boosting firm performance that are pertinent to IP. They consider that networks constitute an "important source of resources..." (p.65) the most cited one of which was information. High centrality of the focal firm, i.e. involved in many ties in the network, make it a "major channel of information". Network closure - generally measured as "ego network density" (p.66) - increases knowledge sharing and trust, and thus lowers transaction costs. However, excessive density, leading to overembeddedness, limits the diversity of information to which firms in the network can access. Referring to Burt (1992), the authors state that "certain network structures (i.e. rich in structural holes) provide more diverse and timelier information than other structures" (p.65).

Zaheer et al. (2010) do not explicitly mention innovation. However, they do so implicitly. Strong ties improve firm performance when exploitation behavior is required, weak ties do so when exploration behavior is necessary. March (1991) distinguished between exploitation and exploration, defining the latter as innovation. Recently, several authors have associated exploration with radical innovation and exploitation with incremental innovation (e.g. Leeuw, Lokshin \& Duysters, 2014; Hooge, Béjean \& Arnoux, 2016).

In addition, diversity of alliances (ties/linkages) and of partners in an $\mathrm{AP} / \mathrm{Net}$ that obviously contribute to the diversity of information and other resources, were considered important for IP in several studies (see Macedo-Soares, Barbosa \& Paula, 2016a).

Although the characteristics of the AP/Net and the relative position of the firm in the AP/Net may influence its IP, other factors are also important.

What is critical is that the firm can derive benefits from the information provided by the AP/Net. This depends on the firm's level of absorptive capacity - AC, i.e. the "ability of a firm to recognize the value of new, external information, assimilate it, and apply it to commercial ends" (Cohen \& Levinthal, 1990, p. 128).

(1) Business School, Pontifical Catholic University of Rio de Janeiro, Rio de Janeiro, Brazil.

*Corresponding author: diana@iag.puc-rio.br 
According to Kim (1997), AC involves two important variables: i) "existing knowledge base ... mostly tacit knowledge" which influences learning processes and is fundamental for the creation of new increased tacit knowledge, ii) ... the intensity of effort.".. "or commitment" (p. 97) to integrate this knowledge.

Most empirical studies on the AP/Net - IP relationship and AC's role in this relationship focus on companies from developed countries (e.g. Beers \& Zand, 2014; Srivastava, Gnyawali \& Hatfield, 2015; Hurmelinna-Laukkanen et al., 2012). Only a few investigate developing/emerging economies, mainly in Asia (e.g. Tsai, 2009; Lião \& Yu, 2013; Yu, 2013), with hardly any concentrating on Latin America (exceptions are García Fernández, Sánchez Limón, \& Sevilla Morales, 2012; Gomez, Daim \& Robledo, 2014).

This article shares research that explored the relationship at issue in developing/emerging countries, specifically in Latin America's largest country and only BRIC member: Brazil. Its objective was to answer the question:

How do AP/Net characteristics of firms in developing/emerging countries in Latin America - in this specific case Brazil - impact their IP and how is this relationship influenced by firms' AC?

For this purpose, we used a model developed in our research's previous stage for analyzing the moderating role of AC in the AP/Net IP relationship in firms in developing/emerging countries that seek to boost their competitiveness by leveraging IP through their AP/Nets.

The remainder of this paper is divided into four sections: i) theoretical references; ii) research methodology; iii) results; iv) discussion; v) concluding remarks.

\section{Theoretical References}

We first summarize the theoretical references that formed the basis for the conceptual model and hypotheses, whose subsequent testing helped answer our research question.

\section{Literature review}

A lot of research has been conducted on the engagement of firms in $\mathrm{AP} /$ Nets as a source of knowledge for improving their IP. MacedoSoares et al. (2016a) found that cutting-edge research conditions the success of a focal firm's AP/Net in terms of leveraging IP to the characteristics of the $\mathrm{AP} / \mathrm{Net}$ and to its $\mathrm{AC}$.

Caner,SunandPrescott(2014) andGilsing, Nooteboom, Venhaverbeke, Duysters and van den Oord (2008), both found that firms which have high network centrality generally have higher exploratory IP. According to Caner et al. (2014) this was because high centrality increased "the positive moderating effect of the acquisition component of AC in the alliance ego-net - IP relationship" (in Macedo-Soares et al., 2016a, p.28). Gilsing et al. (2008) stressed the importance of considering both network density and technological distance when analyzing network centrality.
Lin, Wu, Chang, Wang and Lee (2012) found that there is an inverted $\mathrm{U}$-shaped relationship between AP/Net partner technological distance and IP, and that this relationship is positively moderated by AC, especially when this distance is significant and the portfolio includes a high percentage of R \& D alliances. An inverted U-shaped relationship was also found between the number of existing technological alliances in an AP/Net and IP (Vanhaverbeke, Belderbos, Duysters and Beerkens (2015), and between AP/Net diversity of the AP/Net and IP (Wuyts \& Dutta, 2014; Yu, 2013).

In the literature reviews conducted, respectively, by Macedo-Soares, Turano, Esteves and Porto (2016) and Macedo-Soares et al. (2016a), diversity was found to be the most significant AP/Net characteristic for boosting IP. AC affected the AP/Net - IP relationship differently, depending on the type of AP/Net diversity, as Tsai (2009), for example, made evident, AC's role also varies depending on the type of IP- explorative/radical or exploitative/incremental. Beer and Zand (2014) found positive relationships, respectively, between functional $\mathrm{AP} / \mathrm{Net}$ diversity and radical IP, and between geographic AP/Net diversity and incremental IP. AC helps derive benefits from the firm's prior experience with multiple alliances, which is another fundamental factor for ensuring that AP/Net characteristics boost firm IP.

As regards geographic diversity, Lião and Yu (2013) suggested that $\mathrm{AC}$ has a lesser moderating role in the linkage diversity - IP relationship in the case of international linkages with firms from emerging countries. Differences between developed/emerging countries' AC levels are related to a technology gap in the latter and influenced by institutional diversity.

\section{Conceptual model}

The model adopted in our study features the relationship between a firm's AP/Net characteristics and its IP, as well as AC's influence in this relationship (Figure 1). As explained in Macedo-Soares et al. (2016a), it was based on extensive literature reviews and drew upon Macedo-Soares 's (2011) Global SNA Framework and its variation - the SNA-IF (Strategic Network Analysis Innovation Framework) (Macedo-Soares, 2015).

In this framework AP/Net characteristics for leveraging IP were classified according to the following dimensions: AP/Net Structure (diversity, centrality, size and stability); AP/Net Composition (partner identity, firm and partner resources); AP/Net linkage modalities (explorative/exploitative, generative/attractive), to help assess the characteristics' positive or negative strategic implications at both industry and firm levels.

In the model diversity is highlighted in bold characters among the AP/ Net structure characteristics because of its significance in the AP/Net IP relationship. This is also the case of the explorative and exploitative alliance types in the AP/Net linkage modalities dimension. AC is featured in the AP/Net Management Dimension and is highlighted among other relevant $\mathrm{AP} / \mathrm{Net}$ management capabilities in the center of this dimension, due to the focus on its role. Multiple alliance experience is also 
shown as supporting AC and the other AP/Net management capabilities, in keeping with literature review findings. The two types of IP - radical and incremental - appear in bold type in the Firm Innovation Performance box, together with the constructs used to qualify them. Reverse innovation is not highlighted because it was not investigated. This is also the case of control variables that were identified in the literature, with the exception of firm size. The arrows indicate the direction of the AP/ Net - IP relationship, with the plus sign showing that this relationship is positive. Similarly, in the case of AC, the arrow and plus sign indicate its positive moderating influence on the AP/Net - IP relationship.

Figure 1: Conceptual model (Macedo-Soares et al., 2016a)

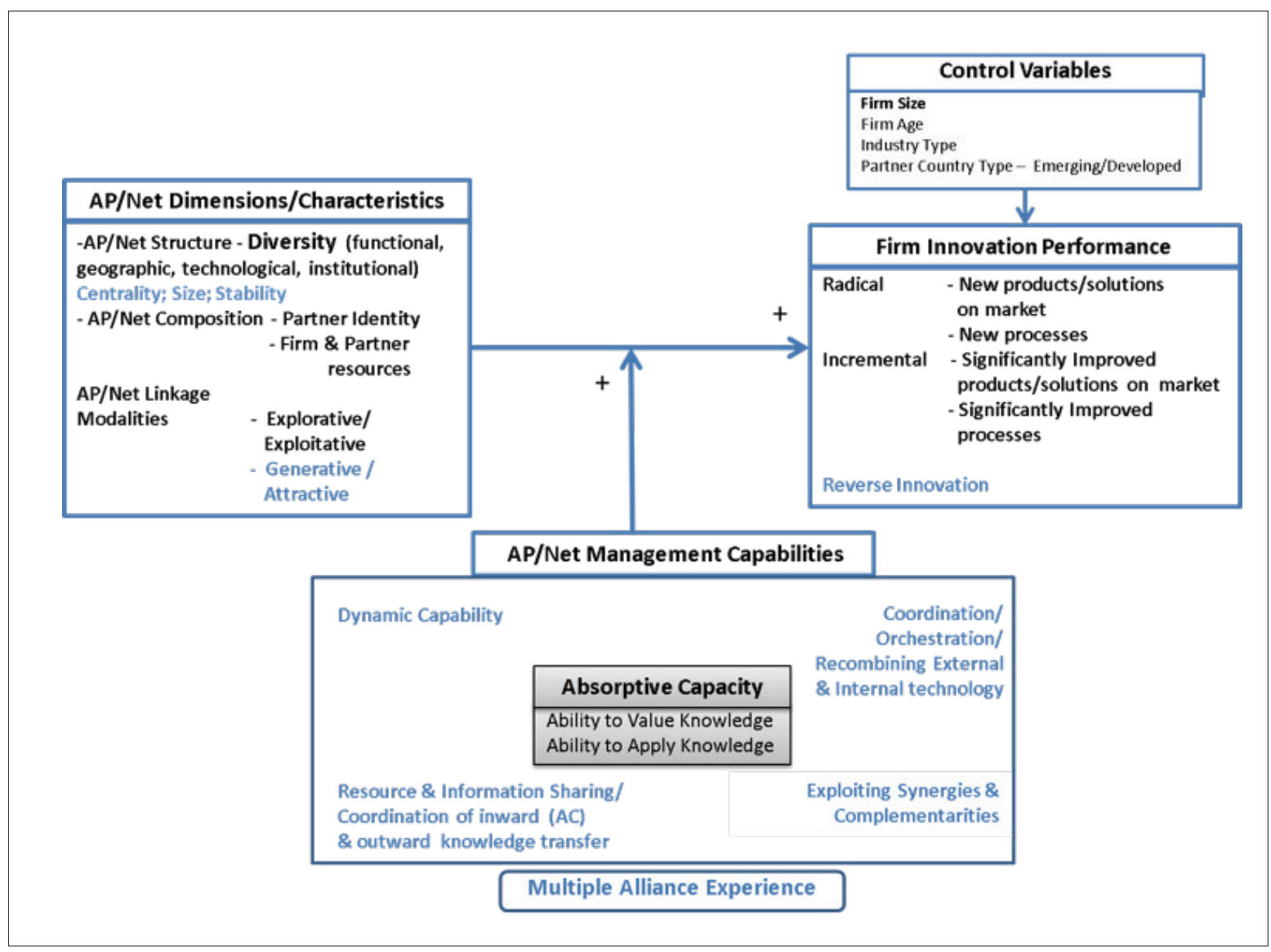

The hypotheses, formulated at this stage in keeping with the relationships shown in the model, are listed below.

\section{Hypotheses}

H1: The innovation performance (radical and incremental) of firms in Brazil engaged in AP/Nets is positively associated with the firm's AP/Net Diversity (functional, geographical, technological and institutional)

H2: The IP (radical and incremental) of firms in Brazil engaged in AP/Nets is positively associated with the strength of the identity of the partners in the firm's AP/Net.

H3: The IP (radical and incremental) of firms in Brazil engaged in $\mathrm{AP} /$ Nets is positively associated with the level of the resources of the firm's AP/Net and of its partners.
H4: The AC level of firms in Brazil positively and linearly moderates the relationship between the above-mentioned firm's AP/Net characteristics (diversity, partners' identity and resources of the focal firm and of its partners in the AP/Net) and the focal firm's IP (radical and incremental).

These hypotheses may be challenged, especially in developing/emerging countries where firms' accumulation of technological capabilities is still not as developed in the most innovative countries (Choung, Hwang, \& Song, 2014; Kim, 1997). In developing/emerging countries, the firms' level of AC may not be high enough to enable them to take advantage of external knowledge sources to improve their IP (Paula \& Silva, forthcoming) and attaining the appropriate level depends not only on the firm itself but on the existence of an institutional infrastructure (i.e. policy support, public research institutes) to support the acquisition of such capabilities (Choung et al., 2014). This could prevent finding the expected positive relationships between 
$\mathrm{AP} / \mathrm{Net}$ and IP. Some studies identified non-positive direct relationships between certain AP/Net characteristics and IP. Notably, Cui and O'Connor (2012) found that high partner diversity may have a negative relationship with IP due to high transaction and AP management coordination costs. Leeuw, Lokshin and Duysters (2014) came to a similar conclusion, attesting that excessive AP/Net diversity accounts for a negative influence on innovation. (See also Caner et al. 2014 and Tsai, 2009). These conflicting findings increase the importance of testing these relationships, using different methods, in an emerging economy - in the case of this article, Brazil.

\section{Research Methodology}

Note that the research presented here is part of a wider investigation conducted in several stages. The previous stages were dedicated to bibliographic studies - both quantitative and qualitative - and the development of the theoretical bases, including the model, for achieving the research's objective. The stage at issue here is the first one in which an empirical study was carried out involving the application of this model.

\section{Data source and sample}

To conduct this research we collected data from two sources: i) a survey to capture data for the proxies of the constructs AP/Net Dimensions/Characteristics, AP/Net Management Capabilities and for some proxies of Firm IP; ii) secondary data from a survey of Finep's beneficiaries' to complement the proxies used for the Firm IP construct with others, as well as some descriptive information regarding the firms, such as their industrial sector and labor force quality.

Finep, founded in 1967, is Brazil's Innovation Agency, and is linked to the Ministry of Science, Technology and Innovation. Its mission is to promote the country's economic and social development by fostering science, technology and innovation in firms, universities, technological institutes and other private and public institutions (Finep, 2016). To achieve these goals, Finep uses grants for companies and universities, cheap credit, equity and quasi-equity investments and non-financial innovation support.

The questionnaire, developed by the authors for carrying out the survey, was pre-tested according to Churchill (1979), using a sample of 70 respondents involved in innovation alliances entered into by CENPES, the research center of Petrobras, the largest Brazilian Oil \& Gas and renewable energy company. Several changes were made to the questionnaire following this test before applying it with the support of the Qualtrics platform (Snow \& Mann, 2013).

The survey aimed at capturing important data from all the firms that had subscribed to "FINEP 30 Dias", the agency's core program to boost innovation in Brazil. Launched in September 2013, this program aims at supporting both Brazilian firms' specific innovation projects and their innovation strategies (Finep, 2016). It is based on the assumption that in Brazil there is a specific group of companies called "technological core of the industry", that could propel the country to a new level of innovation (De Negri \& Lemos, 2011). To bring about the necessary changes, this program needs to understand these companies' innovation strategies, including their dyadic and multilateral alliances.

The number of firms in FINEP's database amounted to 497, of which 70 answered our questionnaire adequately, or a response rate of $15.3 \%$, only slightly below that of other innovation studies in Brazil (Ribeiro et al., 2014; Borba, Neto \& Figueiredo, 2016). We excluded one case from the sample because it appeared as an outlier in many variables ( $z$-score $\geq 3$ ). A special variable in which the case behaved as an outlier was turnover with a $z$-score of 7.94 , indicating that the firm is much bigger than those of the sample.

Of the remaining 69 respondents, $26(37.68 \%)$ were engaged in multilateral alliances. Their data could therefore be used to test our model. It was complemented with data about general characteristics and IP previously collected by FINEP when these companies filled out their application for financial innovation incentives from this agency.

\section{Description of the variables}

As explained earlier, the model involves three interacting constructs: $\mathrm{AP} / \mathrm{Net}, \mathrm{AC}$ and IP. The AP/Net Alliance Portfolio construct was operationalized using the following variables:

i) $\mathrm{AP} / \mathrm{Net}^{\prime} \mathrm{s}$ geographical diversity - number of $\mathrm{AP} / \mathrm{Net}$ partners' different nationalities, considering nine different locations: Brazil; Mercosur countries; Other Latin American countries; USA and Canada; Western Europe; Japan; Eastern Europe and other Asian countries; Africa and Oceania (AP1);

ii) $\mathrm{AP} / \mathrm{Net}^{\prime} \mathrm{s}$ functional diversity - number of different types of AP/Net partners, considering seven different options: clients, suppliers, substitutes, competitors, new entrants, universities/research institutes and government (AP2);

iii) AP/Net technological diversity - degree of technological diversity between the AP/Net partners and the focal firm on a 5 point Likert scale, from ' $0=$ very low' to ' $4=$ very high' (AP3);

iv) Focal firm's value - degree of value of the focal firm as a partner of the AP/Net partners on a 5 point Likert scale, from 0 to 4 (AP4);

v) AP/Net Partners' value - average value for the focal firm of the partner by partner type, from 0 to 4 (AP5);

vi) $\mathrm{AP} / \mathrm{Net}$ Partner resources' richness - average richness of the partner's resources by partner type, from 0 to 4 (AP6);

vii) AP/Net Partner resources' volume - average volume of the partner's resources by partner type, from 0 to 4 (AP7);

viii) AP/Net Partner resources' complementarity - average complementarity of the partner's resources with those of the focal firm by partner type, from 0 to 4 (AP8); 
ix) AP/Net Partner resources' access - average easiness of access to the partner's resources on the part of the focal firm by partner type, from 0 to 4 (AP9);

x) AP/Net strength - average strength of the tie with each partner type from 1 to 7 (AP10);

xi) Exploration / exploitation - averaged by the level of exploration / exploitation for each AP/Net partner type, considering '0 - exploitation' and ' 1 - exploration' (AP11).

xii) AP/Net size - the average number of partners in the firm's AP/ Net (AP12) up to six (the last option is six or more partners);

xiii) Percentage (\%) of alliances in an AP/Net - percentage of alliances of the firm's total number of alliances that are multilateral.

The construct AC was operationalized through a 5-point scale composed of 12 questions (AC1 to AC12) to measure the focal firm's capacity to identify, acquire, assimilate and use the external information to leverage its innovation outcome. This scale was based on Ritala and Hurmelinna-Laukkanen's (2013) potential AC scale. The endogenous construct, Innovation Performance, was operationalized using the following variables;

\section{i) Product Innovation}

a. Percentage (\%) of total turnover from products new to the market (did not innovate / more than 0 to $10 \%$ / more than 10 to $40 \%$ / more than $40 \%$ ) (\%PROD);

b. Product innovation complexity - 0 if no product innovation was introduced by the focal firm in the last five years. If at least one product innovation was introduced during the period, the sum of the level of radicalness of product innovation (1 point if the innovation was incremental and 2 if it was radical) and the degree of innovativeness of product innovation ( 0 point if it was new to the firm, 1 point if it was new to the country and, 2 points if it was new to the world) (IPROD)

ii) Process Innovation

a. Process innovation complexity - 0 if no process innovation was introduced by the focal firm in the last five years. If at least one process innovation was introduced during the period, the sum of the level of radicalness of process innovation ( 1 point if the innovation was incremental and 2 points if it was radical) and the degree of innovativeness of process innovation ( 0 point if it was new to the firm, 1 point if it was new to the country and, 2 points if it was new to the world) (IPROC).

As control variable we used 'firm size', measured by the total number of employees. Other control variables were not used due to a lack of necessary data.

\section{Statistical method}

After calculating the variables' $\mathrm{z}$-score, we conducted an exploratory factor analysis to reduce the dimensions of AP/Net and AC (Hair, Black, Babin, Anderson, \& Tatham, 2006). The variables with individual measure sampling adequacy (MSA) below 0.5 in the anti-image matrices were removed from the analysis. Next, we analyzed the global MSA and whether Bartlett's test of sphericity was significant at $\mathrm{P}$ $<0.05$. The number of factors was chosen by a composition of the eigenvalue $>1$ criteria and the scree plot analysis. The resulting factors were subjected to a varimax rotation and the final dimensions of the constructs were established by a summated scale of the variables with a weight of more than 0.7 in the case of AC. To test the hypotheses we conducted a multiple regression analysis (Hair et al., 2006) to find relationships between the constructs. One regression was run for each dimension of Innovation Performance (Product and Process Innovation) as a dependent variable. The independent variables were the factors for AP/Net and AC that had resulted from the summated scales derived from the factor analysis. The moderation relationship was tested by using the multiplication of the factors that represented AP/Net Characteristics and $\mathrm{AC}$ as independent variables in the regressions.

\section{Results}

According to Brazil's official 2012-2014 Innovation Survey, there was a slight increase in the innovation rate of Brazilian firms: $36 \%$ versus $35.7 \%$ in 2011-2013 (IBGE, 2016). Product innovation improved from $17.3 \%$ to $18.3 \%$ and process innovation from $31.7 \%$ to $32.7 \%$. The R\&D investment rate ( $\%$ of turnover invested in $R \& D$ ) improved very slightly: $0.61 \%$ versus $0.58 \%$ in the previous period. An analysis of the type of investments in innovative activities, reveals a substantial increase (69.4\%) in the external sources of innovation (acquisition of external R\&D and external knowledge): $12.2 \%$ in $2012-2014$ versus $7.2 \%$ in $2009-2011$.

Although the reports evidence an overall increase in innovation activities and innovation outputs in Brazilian firms, and even though Brazil is the $9^{\text {th }}$ economy in the world in terms of GDP (Worldbank, 2017), the country was recently ranked $69^{\text {th }}$ in the Global Innovation Index (Dutta, Lanvin \& Wunsch-Vincent, 2016), which was worse than in 2014 when it occupied the $61^{\text {th }}$ place (Dutta, Lanvin \& Wunsch-Vincent, 2014). These numbers reinforce the urgency of understanding the characteristics of innovation alliances in Brazil, in order to suggest ways to improve firms' IP, considering its importance for sustained growth (Christensen \& Raynor, 2003) and potential to drive the country's economic development as a whole (Kim, 1997).

Table 1 presents some characteristics of the full sample of 69 firms, classified in three groups: Group 1 (7 firms) - firms with no alliances for innovation; Group 2 (36 firms) - firms engaged only in dyadic alliances for innovation; Group 3 (26 firms) - firms operating in AP/Nets for innovation. As Table 1 shows, most firms in the survey had introduced at least one product or process innovation (65 firms, or $94.9 \%$ ), whereas $6.80 \%$ (4 firms) had not, had failed to introduce at least one innovation during the period, or had not even tried. 
A certain positive balance was found between product and process innovation: 57 of the 69 firms had introduced product innovations $(82.6 \%)$, and 59 of the 69 firms had introduced process innovations (85.5\%). This was observed in all three groups. Another characteristic highlighted in Table 1 is the firms' turnover for the last year (2015). There are important differences between the three groups. Group 3 has a higher average (R $\$ 1,318 \mathrm{MM})$ followed by far by Group 2 (R\$47MM) and Group 3 (R\$141MM). These data suggest that innovation-oriented firms in Brazil engaged in AP/Nets are much bigger in terms of turnover than those without alliances or with dyadic alliances for innovation. The difference between Groups 2 and 1 also suggests that firms with dyadic alliance are bigger in terms of turnover than those without innovation alliances.

Because our literature review revealed a positive relationship between exports and innovation capabilities in firms of developing/emerging countries (Gashi, Hashi and Pugh, 2014), thus highlighting their contribution to firm growth (Golovko \& Valentini, 2011), we also conducted an analysis of the relationship between alliance types and exports of the sampled firms. In absolute terms, Group 3 had a much higher export average (110.4 MM) than Group 2 (19.9 MM) or Group 1 (2.3 MM). This difference was also perceived in relative terms -export/turnover ratio, - and similar patterns were found when comparing Groups 3 (14.01\%), 2 (5.71\%) and 1 (4.72\%). These figures suggest that there is a positive relationship between firm's participation in $\mathrm{AP} / \mathrm{Nets}$ and its export volume. Moreover, when considering the number of employees, although the average was close to two thousand $(1,990)$, with $2.34 \%$ dedicated to R\&D, firms that operated in AP/Nets were much bigger, having on average 3,407 employees, with around 56 dedicated to internal $\mathrm{R} \& \mathrm{D}(1.65 \%)$.

Firms engaged only in dyadic alliances were much smaller; although the percentage of people dedicated to internal $R \& D$ was higher $(1,257$ employees on average, with $3.74 \%$ dedicated to R\&D). Firms that had no alliances for innovation were even smaller, with merely a fraction of their employees dedicated to internal R\&D (494 employees and $1.62 \%$ engaged in $\mathrm{R} \& \mathrm{D}$ ). The percentage of employees involved in internal R\&D in each group was consistent with the firm's internal R\&D intensity (the ratio between a firm's spending on internal R\&D and its total turnover). Firms of Group 2 had a higher internal $\mathrm{R} \& \mathrm{D}$ intensity compared to firms from Group 3 (5.62\% vs. $3.54 \%$ ), as they had a greater percentage of employees in $R \& D$, suggesting that firms of this group were more dedicated to internal $R \& D$, in general, than those of the other two groups. External R\&D acquisition intensity (the ratio between the sum of total spending from external R\&D and the firm's total turnover), was also higher in the case of Group 2, with $0.88 \%$ versus $0.57 \%$ for Group 3. As expected, firms of Group 1 that had no alliances for innovation, invested very little in external $R \& D(0.38 \%)$. Since internal $R \& D$ intensity was also low in this group $(0.93 \%)$, we inferred that it was not dedicated to innovative activities and the innovations its firms developed were merely circumstantial.

The percentage of a firm's turnover from new products was somewhat higher for firms that had engaged in dyadic alliances (37.8\% in Group 2 had more than $40 \%$ of their turnover from new products, versus $14.3 \%$ in Group 1 and $11.5 \%$ in Group 3). Group 1 evidently innovated less. Firms of Group 3, however, innovated at a similar level to those in Group 2 (Group 3 - 96.2\% and Group 2 $94.4 \%)$. A possible reason for the difference in the participation of new products in the firm's turnover is that Group 2 may have introduced a higher number of product innovations in the period, which would be consistent with a higher investment in internal R\&D. As we did not have information on the number of products introduced by these firms, no definitive conclusion could be made regarding this point.

Table 1: Characteristics of the sample

\begin{tabular}{|c|c|c|c|c|}
\hline Characteristics & $\begin{array}{c}\text { Group 1 -No } \\
\text { Alliances }(\mathbf{n}=7)\end{array}$ & $\begin{array}{l}\text { Group } 2 \text {-Dyadic } \\
\text { Alliances }(\mathrm{n}=36)\end{array}$ & $\begin{array}{l}\text { Group } 3 \text {-Alliance } \\
\text { Portfolio }(n=26)\end{array}$ & $\begin{array}{l}\text { Total } \\
(n=69)\end{array}$ \\
\hline No innovation introduced & 2 & 2 & 1 & 5 \\
\hline Innovation introduced & 5 & 34 & 25 & 65 \\
\hline Product Innovation & 5 & 30 & 22 & 57 \\
\hline Process Innovation & 5 & 30 & 24 & 59 \\
\hline Avg. Turnover last year (million $R \$$ ) & 142 & 475 & 1,318 & 759 \\
\hline Avg. Number of Employees & 494 & 1,257 & 3,407 & 1,990 \\
\hline \multicolumn{5}{|l|}{$\%$ Turnover from new products } \\
\hline $0 \%$ & 2 & 3 & 1 & 6 \\
\hline $0-10 \%$ & 2 & 9 & 11 & 22 \\
\hline $10-40 \%$ & 2 & 10 & 11 & 24 \\
\hline $40-100 \%$ & 1 & 14 & 3 & 18 \\
\hline Avg. Export Intensity & $4.72 \%$ & $5.41 \%$ & $14.01 \%$ & $8.58 \%$ \\
\hline Avg. \% Employees R\&D ${ }_{1}$ & $1.62 \%$ & $3.74 \%$ & $1.65 \%$ & $2.34 \%$ \\
\hline Avg. Internal R\&D Intensity & $0.93 \%$ & $5.77 \%$ & $3.54 \%$ & $4.44 \%$ \\
\hline Avg. External R\&D Acquisition Intensity & $0.38 \%$ & $0.88 \%$ & $0.57 \%$ & $0.70 \%$ \\
\hline
\end{tabular}

ISSN: 0718-2724. (http://jotmi.org) 
Since our hypotheses concerned AP/Nets, our analysis henceforth focused on the 26 firms in Group 3. The statistics for the variables representing the model's constructs were calculated for this sample. Table
2 presents the means, standard deviations, minimum and maximum values pertinent to the latter.

Table 2: Statistics for the constructs' variables $(n=26)$

\begin{tabular}{|c|c|c|c|c|c|}
\hline Construct & Variable & Mean & S.D. & Min. & Max. \\
\hline \multirow{12}{*}{ AP / Net Characteristics } & Geographical diversity (AP1) & 2.58 & 1.24 & 1 & 6 \\
\hline & Functional diversity (AP2) & 2.46 & 1.21 & 1 & 6 \\
\hline & Technological diversity (AP3) & 4.18 & 0.60 & 3 & 5 \\
\hline & Focal firm's value (AP4) & 4.10 & 0.66 & 3 & 5 \\
\hline & Partners' value (AP5) & 4.06 & 0.81 & 2 & 5 \\
\hline & Partner resources' richness (AP6) & 4.01 & 0.65 & 3 & 5 \\
\hline & Partner resources' volume (AP7) & 3.38 & 0.70 & 2 & 5 \\
\hline & Partner resources' complementarity (AP8) & 1.44 & 0.37 & 1 & 2 \\
\hline & Partner resources' access (AP9) & 1.96 & 0.66 & 1 & 4 \\
\hline & Strength (AP10) & 3.81 & 0.80 & 2 & 5 \\
\hline & Exploration / exploitation (AP11) & 4.12 & 0.71 & 3 & 5 \\
\hline & Size (AP12) & 3.23 & 1.50 & 1 & 5 \\
\hline \multirow{13}{*}{ Absorptive Capacity } & $\%$ of alliances in an AP (AP13) & $67 \%$ & $36 \%$ & $4 \%$ & $100 \%$ \\
\hline & $\mathrm{AC} 1$ & 4.00 & 0.75 & 3 & 5 \\
\hline & AC2 & 4.23 & 0.76 & 2 & 5 \\
\hline & AC3 & 3.65 & 1.02 & 1 & 5 \\
\hline & AC4 & 3.69 & 1.01 & 2 & 5 \\
\hline & AC5 & 3.88 & 0.86 & 2 & 5 \\
\hline & AC6 & 3.73 & 1.22 & 1 & 5 \\
\hline & AC7 & 4.12 & 0.82 & 3 & 5 \\
\hline & AC8 & 3.88 & 0.82 & 2 & 5 \\
\hline & AC9 & 4.23 & 0.82 & 2 & 5 \\
\hline & AC10 & 3.92 & 1.02 & 2 & 5 \\
\hline & AC11 & 3.92 & 0.89 & 2 & 5 \\
\hline & AC12 & 4.38 & 0.64 & 3 & 5 \\
\hline \multirow{3}{*}{ Innovation Performance } & $\%$ Turnover new products (\%PROD) & 1.62 & 0.75 & 0 & 3 \\
\hline & Product Innovation Intensity (IPROD) & 2.96 & 1.08 & 0 & 4 \\
\hline & Process Innovation Intensity (IPROC) & 3.04 & 1.00 & 1 & 4 \\
\hline
\end{tabular}

The first step in this phase was to conduct an exploratory factor analysis to reduce the number of independent variables representing the $\mathrm{AC}$ and $\mathrm{AP} / \mathrm{Net}$ constructs. Two strategies were used. For AC we verified whether we could represent this concept using merely one factor. For this purpose we ran a factor analysis fixing one dimension without any rotation. No variable below 0.5 was excluded according to MSA criteria. We thus obtained a global MSA of 0.720 and the Bartlett's sphericity test had a $\mathrm{X}^{2}$ of 160.363 with $d f$ of 66 and a significance of 0.000 . The total variance explained by the unique factor was $46.906 \%$. Although it was below $50 \%$, for reasons of parsimony, we considered that AC could be represented by this single factor. The final factor was calculated using summated scales of the variables with a weight of 0.7 or more. These were AC4, AC5, AC6 and AC7.
In the case of the AP/Net construct we conducted an exploratory factor analysis choosing the number of dimensions according to eighenvalue $>1$ criteria. AP7 and AP9 were dropped from the analysis because their individual MSAs were lower than 0.5. The global MSA of 0.714 and the Bartlett's sphericity test had a $\mathrm{X}^{2}$ of 111.111 with $d f$ of 55 and a significance of 0.000 . The model resulted in four factors with a total variance of $75.093 \%$. Factor 1 had weights of more than 0.7 for the variables AP3 - value of partners (0.814), AP5 - volume of partners' resources (0.908), AP6 - complementarity of partners' resources (0.779) and AP11 - value of focal firm (0.777). We called this factor AP Resources. Factor 2 had weights of more than 0.7 for the variables AP1 - geographical diversity (0.818), and AP2 - functional diversity (0.839), and were named AP Diversity. Factors 3 and 4 had 
only one variable, AP10 - technological diversity (0.748) and AP8 - exploration/exploitation (0.881) respectively, weighing more than 0.7. We called Factor 3 AP technological breadth and Factor 4 AP level of knowledge exploration / exploitation.

Next, we ran two separate multiple regressions with both variables representing product innovation (\% of total turnover from products new to the market - \%PROD, and product innovation complexity - IPROD) and process innovation complexity (IPROC), as dependent variables to test the hypotheses, totalizing six regressions. For each dependent variable, one regression was run only with the AP/Net and AC factors followed by another introducing the interacting variables. As the dependent variables were not normal they were transformed using reciprocal transformation (Box \& Cox, 1964), after adding 1 to the original variable to avoid zero values in the denominator, having respectively $1 /(1+\%$ PROD $), 1 /(1+$ IPROD $)$ and $1 /(1+$ IPROC $)$. Although the transformed variables were still not normal, they improved the regression results and we continued our analysis with them.

The results of the regressions were not significant for the transformed \%PROD (F-statistics $=0.610$, with a significance of 0.783 for the complete model) and IPROC (F-statistics $=0.678$, with a significance of 0.729 for the complete model). Therefore, we proceeded using only the regression of IPROD (see Table 3). The analysis strongly suggested that the model improved significantly if the moderation of AC on the AP/Net characteristics was added to the model. Model 1 that used only the isolated factors of AP and AC as independent variables was not significant $(\mathrm{p}<0.1)$. When we added the moderation variables (Model 2) we found a significant improvement in the F-statistic of 3.048 and the model was significant with $\mathrm{p}<0.1$. AC by itself improved the product innovation complexity level, with a $\beta=-0.403(\mathrm{p}<0.1)$. The negative load represented a positive influence on the level of product innovation complexity as the variable in the regression received a reciprocal transformation beforehand. The only AP factor that was also significant was $A P$ diversity $(\beta=0.425$ with $\mathrm{p}<0.1)$ and it had a negative influence on product innovation complexity. These results were consistent with previously mentioned studies which found that AP/Net diversity may have a negative impact on IP by increasing AP management complexity and costs (Cui \& O'Connor, 2012; Leeuw et al., 2014).

Our findings led us to reject Hypotheses 1, 2 and 3, as the effect of diversity was found to be negative instead of positive, and the other firms' characteristics had no significant direct effect on the level of radical and incremental product innovation (represented by product innovation complexity).

Table 3: Results of the multiple linear regression with independent variable Product Innovation Complexity (with reciprocal transformation)

\begin{tabular}{|c|c|c|c|c|}
\hline \multirow[b]{2}{*}{ Dependent Variable: Product Innovation Complexity (transformed) } & \multicolumn{2}{|c|}{$\begin{array}{c}\text { Model } 1\left(\mathrm{R}^{2}=0.269 ; \text { Adj }\right. \\
\left.\mathrm{R}^{2}=0.038\right)\end{array}$} & \multicolumn{2}{|c|}{$\begin{array}{c}\text { Model } 2\left(\mathrm{R}^{2}=0.590 ; \text { Adj }\right. \\
\left.\mathrm{R}^{2}=0.317\right)\end{array}$} \\
\hline & $\beta$ & $\begin{array}{l}\text { Std. } \\
\text { Error }\end{array}$ & $B$ & $\begin{array}{l}\text { Std. } \\
\text { Error }\end{array}$ \\
\hline \multicolumn{5}{|l|}{ Factors } \\
\hline Firm size & -0.020 & 0.044 & -0.148 & \\
\hline Absorptive capacity & -0.326 & 0.054 & $-0.403^{*}$ & 0.05 \\
\hline AP resources & -0.291 & 0.059 & -0.127 & 0.05 \\
\hline AP diversity & 0.304 & 0.048 & $0.427^{\star}$ & 0.05 \\
\hline AP technological breadth & 0.047 & 0.046 & -0.074 & 0.04 \\
\hline AP level of knowledge exploration/ exploitation in the AP & -0.069 & 0.043 & 0.068 & 0.04 \\
\hline \multicolumn{5}{|l|}{ Moderation effects } \\
\hline Absorptive capacity x AP resources & & & 0.255 & 0.05 \\
\hline Absorptive capacity x AP diversity & & & $-0.529^{* *}$ & 0.06 \\
\hline Absorptive capacity x AP technological breadth & & & -0.091 & 0.05 \\
\hline $\begin{array}{l}\text { Absorptive capacity x AP level of knowledge exploration/ex- } \\
\text { ploitation }\end{array}$ & & & -0.139 & 0.06 \\
\hline Model F & 1.163 & & $2.162^{*}$ & \\
\hline Change in $\mathrm{F}$ & & & $3.048^{*}$ & \\
\hline
\end{tabular}

However, when we tested the interaction of AP/Net diversity with $\mathrm{AC}$, the latter had a significant positive influence on product innovation complexity $(\beta=-0.529$ with $\mathrm{p}<0.05)$. The other interacting fac- tors were not significant. We thus partially accepted Hypothesis 4 . The regression did not find any significant effect of firm size on product innovation complexity. 


\section{Discussion and Concluding Remarks}

In order to discuss our study's results it is important to recall its central question: How do AP/Net characteristics of firms in developing/ emerging countries in Latin America - in this specific case Brazil - impact their IP and how is this relationship influenced by firms' AC?

Our study identified three groups of innovation-oriented firms in Brazil: i) firms with no innovation alliances, that invested very little in innovation development; ii) firms engaged only in dyadic alliances and that invested more in internal and external R\&D; iii) firms involved in AP/Nets. Firms in the third group were the most successful ones, as they were bigger, both in terms of revenues and number of employees. They also exported more - an indicator that they were more competitive in the international market (Azar \& Ciabuschi, 2016; Rodil, Vence, \& Sánchez, 2014) it is also based on the complementary assumption that internationalization pushes firms to increase innovation performance (learning-by-exporting hypothesis.

Such positive performance results for firms engaged in AP/Nets, with lower $R \& D$ expenditures (both internal and external $R \& D$ ), reinforced the importance of understanding the impact of AP/Net characteristics on IP and the role of $\mathrm{AC}$ in the $\mathrm{AP} / \mathrm{Net}$ - IP relationship.

However, as mentioned earlier, our study revealed that several AP/ Net characteristics did not have a positive impact on IP in the case of innovation-oriented firms in Brazil. It suggested that the firms' AP/ Net partner resources and their identity were not significantly related to product innovation, and that AP/Net diversity had a negative relationship with IP. As already noted, these results were consistent with previously cited studies (Cui \& O'Connor, 2012; Leeuw et al., 2014; Paula \& Silva, forthcoming), which found that diversity influenced innovation outcomes negatively because it increased coordination and transaction costs.

What is most important, however, is that our research made evident that the negative impact of AP/Net diversity could be mitigated by improving the firm's level of AC. It indeed strongly suggested that AC moderates the relationship between AP/Net diversity and product innovation positively, indicating that "the ability of a firm to recognize the value of new, external information, assimilate it, and apply it to commercial ends" (Cohen \& Levinthal, 1990) is a dynamic capability that is vital for enabling firms to succeed in their endeavors to leverage IP through their AP/Nets.

As observed earlier, in developing/emerging economies firms' level of AC is on average lower than in developed ones. Thus, the ability of firms in these economies to attain a reasonably high level of AC is fundamental for boosting their IP. However, it is not easy for them to achieve this on their own. Including international partners from developed countries in their AP/Nets and engaging in global production networks could enhance the development of their technological capabilities. This would contribute to narrowing the technology gap in these countries and thus boost their firms' level of AC so that the latter could exert its positive moderating role in the AP/Net - IP relationship, thus also making these firms more competitive in the international market (Choung, Hwang and Song, 2014; Paula \& Silva, forthcoming).

Our study enabled us also to draw some public policy implications for innovation-oriented firms in Brazil and possibly other emerging countries with a similar innovation profile. In Brazil more than $63 \%$ of innovations in the last years were process innovations (IBGE, 2016). However, in the last four years most public funding, notably by Finep, was for product innovations (61\% of the total) (IBGE, 2016) aimed at developing products that add new value and do not merely enhance existing processes, so as to increase the country's exports and competitiveness. To improve the results of public funding, in terms of bringing about the desired level of product innovations through firms' AP/Nets, our study's results show that public policies should consider financing programs designed to increase these firms' AC levels. It should prioritize financing programs for firms in $\mathrm{AP} / \mathrm{Nets}$ that include partners such as universities and research centers, as well as foreign partners from countries with the necessary technological capabilities, thus encouraging firms to operate in the above-mentioned global production networks.

Regarding the study's limitations, we should mention the limited number of cases, which did not permit the consideration of industry effects on the relationships. In addition, we lacked access to data on the firms' age, an important control variable. Moreover, our study was restricted to firms in Brazil. Although Brazil is representative of an emerging country and several conclusions may be extended to other emerging economies, part of the results may be country specific. According to Choung et al. (2014), the country's institutional infrastructure also has a critical role in enhancing firms' AC level. Our literature review highlighted the importance of institutional factors, particularly AP/Net institutional diversity, in developing/emerging countries in terms of their ability to influence the level of AC. We could not investigate AP/Net institutional diversity as we lacked access to international partners in the AP/Net.

We thus recommend that future studies consider institutional factors that are specific to the country at issue and to the AP/Net's partners. Studies comparing developing/emerging countries, such as Brazil, with developed ones could investigate differences in firms' AC levels and $\mathrm{AC}^{\prime}$ 's role in improving the AP/Net - IP relationship in both types of countries.

\section{References}

Ahuja, G. (2000). Collaboration Networks, Structural Holes, and Innovation: A Longitudinal Study. Administrative Science Quarterly, 45(3), 425.

Azar, G., \& Ciabuschi, F. (2016). Organizational innovation, technological innovation, and export performance: The effects of innovation radicalness and extensiveness. International Business Review. 
Beers, C. \& Zand, F. (2014). R\&D Cooperation, Partner Diversity, and Innovation Performance: An Empirical Analysis. Journal of Product Innovation Management, 31(2), 292-312.

Borba, M., Neto, C.G., Figueiredo, O. (2016). Open innovation in the oil and gas industry in Brazil. 25th International Association for Management of Technology Conference, IAMOT 2016, Orlando, May 2016.

Box, G. E., \& Cox, D. R. (1964). An analysis of transformations. Journal of the Royal Statistical Society. Series B (Methodological), 211-252.

Burt, R. S. (1992). Structural holes: The structure of social capital competition. MA: Harvard University Press, Cambridge.

Caner, T., Sun, J., \& Prescott, J. E. (2014). When a firm's centrality in R\&D alliance network is (not) the answer for invention: The interaction of centrality, inward and outward knowledge transfer. Journal of Engineering and Technology Management, 33, 193-209.

Chesbrough, H. W. (2006). Open innovation: The new imperative for creating and profiting from technology. Harvard Business Press.

Choung, J. Y., Hwang, H. R., \& Song, W. (2014). Transitions of innovation activities in latecomer countries: an exploratory case study of South Korea. World Development, 54, 156-167.

Christensen, C., \& Raynor, M. (2013). The Innovator's Solution: Creating and Sustaining Successful Growth. Harvard Business Review Press.

Churchill Jr, G. A. (1979). A Paradigm for Developing Better Measures of Marketing Constructs. Journal of Marketing Research, 64-73.

Cohen, W. \& Levinthal, D. (1990). Absorptive Capacity: A New Perspective on Learning and Innovation. Administrative Science Quarterly, 35(1), 128-152.

Cui, A. S., \& O’Connor, G. (2012). Alliance portfolio resource diversity and firm innovation. Journal of Marketing, 76(4), 24-43.

Dahlander, L., \& Gann, D. M. (2010). How open is innovation? Research Policy, 39(6), 699-709.

De Negri, J. A., Lemos, M. B., Ruiz, R. M., \& De Negri, F. (2011). Empresas líderes na indústria brasileira: recursos, estratégias e inovação. $O$ núcleo tecnológico da indústria brasileira. Brasília: Ipea, Finep, Abdi, 1, 11-56.

Dutta, S., Lanvin, B., \& Wunsch-Vincent, S. (2014). The global innovation index 2014: Winning with global innovation. The Global Innovation Index: The Human Factor in Innovation.

Dutta, S., Lanvin, B., \& Wunsch-Vincent, S. (2016). The global innovation index 2016: Winning with global innovation. The Global Innovation Index: Winning with Global Innovation.

Duysters, G. \& Lokshin, B. (2011). Determinants of Alliance Portfolio Complexity And Its Effect On Innovative Performance Of Companies. Journal of Product Innovation Management, 28(4), 570-585.
Faems, D.; Van Looy, B. \& Debackere, K. (2005). Interorganizational Collaboration and Innovation: Toward a Portfolio Approach. Journal of Product Innovation Management, 22(3), 238-250.

Finep (2016, December 22). About Finep. In: http://www.finep.gov.br/about-finep.

García Fernández, F., Sánchez Limón, M., \& Sevilla Morales, J. Á. (2012). Absorptive capacities of local enterprises from the electricelectronics sector in the state of Tamaulipas, Mexico. Journal of Technology Management \& Innovation, 7(1), 128-143.

Gashi, P., Hashi, I., \& Pugh, G. (2014). Export behaviour of SMEs in transition countries. Small Business Economics, 42(2), 407-435.

Gilsing, V., Nooteboom, B., Vanhaverbeke, W., Duysters, G. \& Van Den Oord, A. (2008). Network Embeddedness And The Exploration of Novel Technologies: Technological Distance, Betweenness Centrality And Density. Research Policy, 37(10), 1717-1731.

Golovko, E., \& Valentini, G. (2011). Exploring the complementarity between innovation and export for SMEs' growth. Journal of international Business Studies, 42(3), 362-380.

Gomez, F. A., Daim, T. U., \& Robledo, J. (2014). Characterization of the Relationship Between Firms and Universities and Innovation Performance: The Case of Colombian Firms. Journal of Technology Management \& Innovation, 9(1), 70-83.

Gulati, R., Nohria, N., \& Zaheer, A. (2000). Strategic networks. Strategic Management Journal, 203-215.

Hair, J. F., Black, W. C., Babin, B. J., Anderson, R. E., \& Tatham, R. L. (2006). Multivariate Data Analysis, Pearson Prentice Hall. Upper Saddle River, NJ.

Hooge, S., Béjean, M., \& Arnoux, F. (2016). Organising for radical innovation: The benefits of the interplay between cognitive and organisational processes in KCP workshops. International Journal of Innovation Management, 20(04), 1640004.

Hurmelinna-Laukkanen, P., Olander, H., Blomqvist, K., \& Panfilii, V. (2012). Orchestrating R\&D networks: Absorptive capacity, network stability, and innovation appropriability. European Management Journal, 30(6), 552-563.

IBGE (2017, January 15). PINTEC 2016 Research. In:

http://www.pintec.ibge.gov.br/

Kim, L. (1997). Imitation to innovation: The dynamics of Korea's technological learning. Harvard Business Press.

Knoke, D. (2001), Changing organizations: Business networks in the new political economy, Westview Press.

Laursen, K., \& Salter, A. (2006). Open for innovation: the role of openness in explaining innovation performance among UK manufacturing firms. Strategic Management Journal, 27(2), 131-150. 
Leeuw, T. de, Lokshin, B., \& Duysters, G. (2014). Returns to alliance portfolio diversity: The relative effects of partner diversity on firm's innovative performance and productivity. Journal of Business Research, 67(9), 1839-1849.

Lião, T. J. \& Yu, C. M. J. (2013). The Impact of Local Linkages, International Linkages, and Absorptive Capacity on Innovation for Foreign Firms Operating in an Emerging Economy. The Journal of Technology Transfer, 38(6), 809-827.

Lin, C., Wu, Y.J.; Chang, C.; Wang, W. \& Lee, C. Y. (2012). The Alliance Innovation Performance of R\&D Alliances - The Absorptive Capacity Perspective. Technovation, 32(5), 282-292.

Macedo-Soares, T. D. L. van Aduard De (2011). Ensuring Dynamic Strategic Fit of Firms That Compete Globally in Alliances and Networks: Proposing the Global SNA - Strategic Network Analysis -Framework. Revista de Administração Pública, 4 (1), 67-105.

Macedo-Soares, T. D. L. van Aduard (2015). CNPq Project No. 302213/2014-7.

Macedo-Soares, T. D. L. van Aduard; Turano, L.; Esteves, F. \& Porto, C. B. (2016). International Alliance Portfolios and Innovation: A Proposal for an Analytical Model Based on Bibliographic and Bibliometric Research, Journal of Global Business and Technology. 12(1), 1-22.

Macedo-Soares, T. D. L. van Aduard; Barboza, T. S. \& Paula, F. de O. (2016 a). Absorptive Capacity, Alliance Portfolios and Innovation Performance: An Analytical Model Based on Bibliographic Research, Journal of Technology Management and Innovation, 11(3), 21-32.

March, J. G. (1991). Exploration and Exploitation in Organizational Learning. Organization Science 2(1), 71-87.

Ozcan, P., \& Eisenhardt, K. M. (2009). Origin of alliance portfolios: Entrepreneurs, network strategies, and firm performance. Academy of Management Journal, 52(2), 246-279.

Paula, F.O. \& Silva, J.F (forthcoming). Innovation Performance of Italian Manufacturing Firms: The Effect of Internal and External Knowledge Sources. European Journal of Innovation Management.

Petrobras (2016, December 27). Petrobras Amplia Centro de Pesquisas. In: http://fatosedados.blogspetrobras.com.br/2010/10/07/petrobras-amplia-centro-de-pesquisas/.

Randhawa, K., Wilden, R., \& Hohberger, J. (2016). A bibliometric review of open innovation: Setting a research agenda. Journal of Product Innovation Management, 33(6), 750-772
Ribeiro F. C. F., Miranda Jr., M. O., Borini F. M. \& Bernardes R. (2014). Accelerated Internationalization in Emerging Markets: Empirical Evidence from Brazilian Technology-Based Firms. Journal of Technology Management \& Innovation. 9 (1), 1-12.

Ritala, P., \& Hurmelinna-Laukkanen, P. (2013). Incremental and Radical Innovation in coopetition - The Role of Absorptive Capacity and Appropriability. Journal of Product Innovation Management, 30(1), 154-169.

Rodil, Ó., Vence, X., \& Sánchez, M. del C. (2014). The relationship between innovation and export behavior: The case of Galician firms. Technological Forecasting and Social Change, 113 (1), 248-265.

Snow, J., \& Mann, M. (2013). Qualtrics survey software: Handbook for Research Professionals.

Srivastava, M. K., Gnyawali, D. R., \& Hatfield, D. E. (2015). Behavioral implications of absorptive capacity: The role of technological effort and technological capability in leveraging alliance network technological resources. Technological Forecasting and Social Change, 92, 346-358.

Tsai, K.-H. (2009). Collaborative Networks and Product Innovation Performance: Toward a Contingency Perspective. Research Policy, 38(5), 765-778.

Vanhaverbeke, W., Belderbos, R., Duysters, G., \& Beerkens, B. (2015). Technological performance and alliances over the industry life cycle: evidence from the ASIC industry. Journal of Product Innovation Management, 32(4), 556-573.

Wassmer, U. (2010). Alliance portfolios: A review and research agenda. Journal of Management, 36(1), 141-171.

WorldBank (2017, January 15). World Development Indicators. Retrieved from http://data.worldbank.org/data-catalog/world-development-indicators

Wuyts, S. \& Dutta, S. (2014). Benefiting from Alliance Portfolio Diversity: The Role of Past Internal Knowledge Creation Strategy. Journal of Management, 40(6), 1653-1674.

Xu, S., Fenik, A. P., \& Shaner, M. B. (2014). Multilateral Alliances and Innovation Output: The Importance of Equity and Technological Scope. Journal of Business Research, 67(11), 2403-2410.

Zaheer, A., Gözübüyük, R., \& Milanov, H. (2010). It's the Connections: The Network Perspective in Interorganizational Research. The Academy of Management Perspectives, 24(1), 62-77. 
